\title{
Assessment of the conservation value of dry grassland habitats in the Inhulets River basin (Central Ukraine) based on vegetation and spider research
}

\author{
Nina Polchaninova, ${ }^{1, *(1)}$, Olga Krasova ${ }^{2}$ (i) Liudmyla Lysohor $^{3}$ (i) \& \\ Tatiana Atemasova ${ }^{1}$
}

Key words: conservation areas, protected plant species, spider fauna, steppe habitats, Ukraine.

Ključne besede: naravovarstvena območja, zavarovane rastlinske vrste, pajki, stepski habitati, Ukrajina.

Received: 31. 03. 2020

Revision received: 16.12 .2020

Accepted: 28. 12. 2020

Co-ordinating Editor:

Stephen Venn

\begin{abstract}
Dry grassland ecosystems are highly fragmented in Ukraine and increasingly threatened from intensification of farming practices. Evaluation of the habitat conservation importance based on multitaxon studies allows for optimizing selection of priority sites. Botanical research of xerothermic habitats in the Kryvorizkyi Iron Ore Basin has been conducted since 2012, while spiders were investigated for the first time in 2017. In the four study sites, we recorded 265 vascular plant species (23 under protection) and 95 spider species (19 are rare). Both vegetation and spider communities of the site Zelena Gully are well preserved and rich in rare and threatened species (18 plant and 11 spider species), which confirms its value as a priority site of the Emerald Network. Chervona Gully and the Slate Rocks should be included in the network. Frequent fires and intensive grazing in Khrystoforova Gully affect the spider diversity, decreasing the number of specialist and rare species, while early flowering plants benefit from this disturbance. Nevertheless, its vegetation is poorer than in Zelena and Chervona gullies. Inclusion in the Emerald Network is critically important to the investigated sites, since expansion of mining activities is constantly threatening natural habitats in industrial regions.
\end{abstract}

Izvleček

Suha travišča so močno fragmentiran ekosistem v Ukrajini, ki jih močno ogroža intenzifikacija kmetijstva. Vrednotenje naravovarstvenega pomena na osnovi raziskav večih taksonov omogoča optimalno izbiro prioritetnih območij. Botanične raziskavekserotermnih habitatov na območju nahajališča železove rude Kryvorizkyi, potekajo od leta 2012, pajke pa smo prvič preučili leta 2017. Na štirih raziskovanih območjih smo zabeležili 265 rastlinskih vrst (23 zavarovanih) in 95 vrst pajkov. Vegetacija in združbe pajkov so v jarku Zelena dobro ohranjene $s$ številnimi redkimi in ogroženimi vrstami (18 rastlin in 11 pajkov), kar potrjuje uvrstitev kot prioritetnega območja v omrežju Emerald, v katerega bi morali vključiti tudi jarek Chervona in skrilasto skalovje. Pogosti požari in intenzivna paša v jarku Khrystoforova vplivajo na pestrost pajkov ter zmanjšanje števila specialistov in redkih vrst, po drugi strani pa ta motnja ustreza zgodaj cvetočim rastlinam . Klub temu je vegetacija vrstno siromašnejša kot v jarkih Zelena in Chervona. Vključitev v omrežje Emerald je kritično pomembna za preučevana območja, saj širitev rudarskih aktivnosti predstavlja stalno grožnjo naravnim habitatom v industrijskih regijah.

\footnotetext{
1 V. N. Karazin Kharkiv National University, 4, Maidan Svobody, Kharkiv 61022, Ukraine. E-mail: n.polchaninova@karazin.ua,

2 Kryvyi Rih Botanical Garden of the National Academy of Sciences of Ukraine, 50, Marshaka Str., Kryvyi Rih 50089, Ukraine. E-mail: kras.kbs.17@gmail.com

3 Kryvyi Rih State Pedagogical University, 54 Gagarin Av, Kryvyi Rih, 50086, Ukraine. E-mail: lisogor1981@gmail.com

* Corresponding author
} 


\section{Introduction}

The problem of biodiversity loss has become global and it continues to escalate under increasing pressure of industrial society. Given high fragmentation of natural ecosystems in the steppe zone of Ukraine, virtually every dry grassland area preserved in the agro-industrial landscape is of great conservation importance. These islands of native steppe biota are the refuges for many species, which can colonize abandoned and arable lands (Öberg et al. 2008, Knappová et al. 2012), and thus promote biodiversity and ecosystem sustainability (Tamme et al. 2010, Poggio et al. 2010, Harlio et al. 2019).

A current mechanism of effective phyto- and habitat diversity conservation in Europe is the inclusion of natural vegetation refugia into Natura 2000, a network of nature protection areas in the territory of the EU. The Emerald Network serves the same purpose in non-EU countries. The theoretical basis for these networks is a habitat concept formulated at the Berne Convention on Conservation of European Wildlife and Natural Habitats (Convention 1979). In Ukraine, the Emerald Network has been developing since 2009; however, the dry grassland habitats were included in it only in 2016 (see Kuzemko et al. 2018).

It is advisable to assess the conservation value of a given area using multitaxon studies as they enable the development of adequate measures for preserving biodiversity (Birkhofer et al. 2015, Harlio et al. 2019). Therefore, joint vegetation and invertebrate researches are valuable (Braschler \& Baur 2016, Zao et al. 2018, Outhwaite et al. 2020), since the taxa responses to the same impact are far from being uniform (Niemelä \& Baur 1998, Lafage et al. 2015, Polchaninova et al. 2019).

Spiders are known as indicators of environmental changes (Rodriguez-Artigas et al. 2016, Zografou et al. 2017), habitat structure (Buchholz 2010), and management (Batáry et al. 2012, Polchaninova et al. 2019) of dry grassland ecosystems. It is reasonable to use spiders in nature conservation studies, since they are numerous, diverse in ecological preferences, and inhabit all vegetation layers in various biotops (Perner \& Malt 2003, Cardoso et al. 2004, Szmatona-Túri et al. 2019).

Criteria for the assessment of spider species vulnerability in Ukraine have not developed, and the order Araneae is absent from the National Red List. Some spiders are protected at the regional level, thus, six species are listed in the Red Data Book of Kharkiv Region, and 12 species in the Red Book of Donetsk Region (Tokarsky 2013, Zalevskiy \& Bronskov 2017). Moreover, 80 species from the Ukrainian Carpathians are included in the Carpathian Red List of Forest Habitats and Species (Gajdoš et al. 2014). Dry grassland spiders are studied relatively well in Left-Bank
Ukraine (a region stretching east from the left bank of the Dnieper River to the state border). The faunistic and ecological data were summarized in the Catalogue of spiders of Left-Bank Ukraine and its Addendum (Polchaninova \& Prokopenko 2013, 2017), where "steppe" as a habitat was recorded for 370 species. Contrastingly, arachnological research on the right-bank steppes of Ukraine is at the initial stage. The investigations were conducted only in some localities in Odeska (Deli, 2014), Mykolaivska (Polchaninova et al. 2017) and Khersonska (Prokopenko \& Zhukov 2018, Iosypchuk 2019) oblasts. Prior to our studies, the invertebrate research in the Inhulets basin concerned only grounddwelling insects (Smetana \&Smetana 2005). Preliminary data on spider species richness and xerothermic habitats of the area in question are given in Krasova et al. 2020.

The aim of the present paper is (1) to compile a list of dry grassland habitats of the study area in accordance with the National Habitat Catalogue of Ukraine (Kuzemko et al. 2018); (2) to reveal rare species of the dry grassland flora and spider fauna; (3) to analyze specificity of spider assemblages in the study habitats; (4) to assess conservation value of the study sites based on both IPA criteria and diversity of spider communities.

\section{Material and methods}

\section{Study area and sampled sites}

The Ingulets River, the largest right tributary of the Dnieper lower reaches, has a length of $549 \mathrm{~km}$. It crosses the Dnieper Upland and the Black Sea Lowland in the sub-meridian direction. Four smaller rivers, the Saksahan, the Zelena, the Zhovta and the Bokova, as well as a number of large gullies with permanent streams, flow into the Inhulets in its middle reaches. The natural hydrographic network has been partly destroyed during the ironstone mine workings.

In terms of geo-botanical regions, the area belongs mainly to the Buh-Dnieper (Kryvyi Rih) district of forbfescue-feather grass steppes, bairak forests (natural forests in the gullies in steppe and forest-steppe zones), and the vegetation of granite outcrops within the Black Sea-Azov steppe subprovince of the Pontic Steppe province of the Steppe subregion of Palearctic. The southern part of the study area is located in the same subprovince, in the BuhInhul district of the fescue-feather grass steppes, steppelike meadows and the vegetation of limestone outcrops (Didukh \& Shelyag-Sosonko 2003). Steppe habitats of today in the Inhulets basin have been preserved exclusively as sloping biotopes in the gully and river systems.

The research was conducted in four localities in the vicinity of the town of Kryvyi Rih, Dnipropetrovska Oblast (Figure 1, 2): 

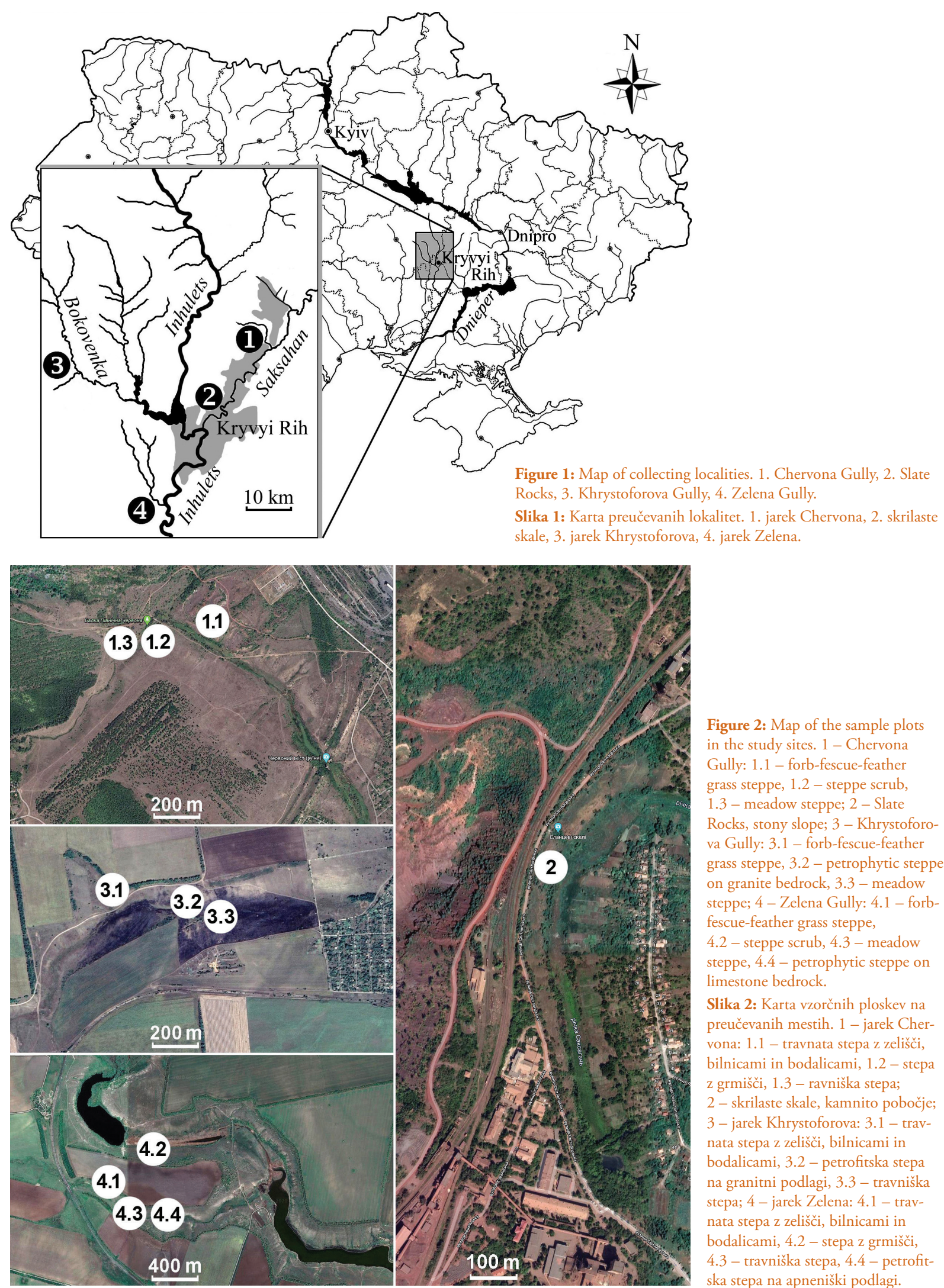

Figure 2: Map of the sample plots in the study sites. 1 - Chervona Gully: 1.1 - forb-fescue-feather grass steppe, 1.2 - steppe scrub, 1.3 - meadow steppe; 2 - Slate Rocks, stony slope; 3 - Khrystoforova Gully: 3.1 - forb-fescue-feather grass steppe, 3.2 - petrophytic steppe on granite bedrock, 3.3 - meadow steppe; 4 - Zelena Gully: 4.1 - forbfescue-feather grass steppe, 4.2 - steppe scrub, 4.3 - meadow steppe, 4.4 - petrophytic steppe on limestone bedrock.

Slika 2: Karta vzorčnih ploskev na preučevanih mestih. 1 - jarek Chervona: 1.1 - travnata stepa z zelišči, bilnicami in bodalicami, 1.2 - stepa z grmišči, 1.3 - ravniška stepa; 2 - skrilaste skale, kamnito pobočje; 3 - jarek Khrystoforova: 3.1 - travnata stepa z zelišci, bilnicami in bodalicami, 3.2 - petrofitska stepa na granitni podlagi, 3.3 - travniška stepa; 4 - jarek Zelena: 4.1 - travnata stepa z zelišči, bilnicami in bodalicami, 4.2 - stepa z grmišči, 4.3 - travniška stepa, 4.4 - petrofitska stepa na apneniški podlagi. 
1. Kryvyi Rih Town, Chervona Gully, geographic coordinates of the central part of the study site $48^{\circ} 06^{\prime} 15.5^{\prime \prime} \mathrm{N}$ $33^{\circ} 31^{\prime} 02.8^{\prime \prime} \mathrm{E}$ (Figure 3). The middle part of the gully with a chain of small quartzite rocks has the status of a geological preserve of local importance; an area of 28.3 ha has a status of a landscape preserve of national importance. The gully is located on the outskirts of the town and borders an iron ore quarry and its waste banks. A stream runs along the gully bottom, the alongside meadows are partly used as a cattle pasture. The gully is crossed by paths but in general the vegetation is not trampled.

2. Kryvyi Rih Town, Slate Rocks, $47^{\circ} 56^{\prime} 27.8^{\prime \prime N} 33^{\circ} 23^{\prime}$ 18.5"E (Figure 4). Geological monument of nature of local importance. It is a chain of amphibolite and slate rocks $20 \mathrm{~m}$ high and $250 \mathrm{~m}$ long, preserved in the urban ecosystem. The site is often visited by holidaymakers.

3. Kudasheve Village, Khrystoforova Gully, 47057'46.5"N $33^{\circ} 04^{\prime} 14.4 " \mathrm{E}$ ( Figure 5). A shallow gully with gentle slopes and small patches of granite outcrops on the lower slopes. The gully is used as a pasture and often experiences chaotic burning. In the study year, nearly the entire gully was burnt in early spring.

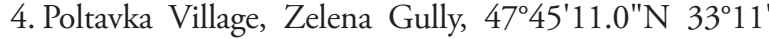
21.3"E (Figure 6). The gully stretches across the border of the forb-fescue-feather grass and fescue-feather grass steppe subzones. Carbonate substrata (limestone) surface on the lower parts of north-facing slopes and provide accumulation of thick diluvium along the bottom. The investigated part of the gully is rarely visited by people.
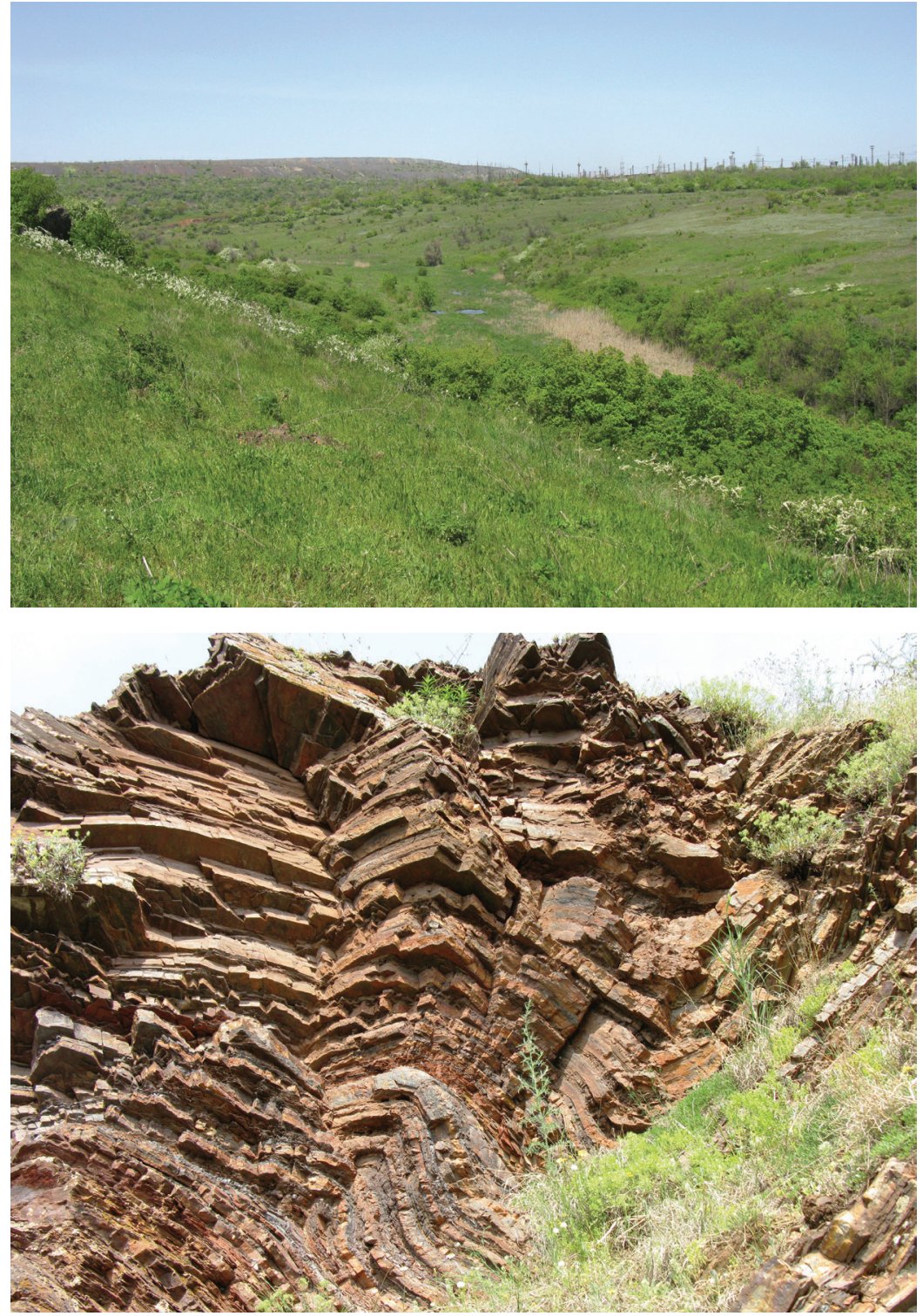

Figure 3: Chervona Gully, May 2017 The gully is adjacent to the iron ore quarry (background). Photo: Nina Polchaninova. Slika 3: Jarek Chervona, maj 2017. Jarek je v bližini izkopa železove rude (v ozadju). Foto: Nina Polchaninova.
Figure 4: Slate Rocks, May 2017. Photo: Nina Polchaninova. Slika 4: Skrilaste skale, maj 2017. Foto: Nina Polchaninova. 
Figure 5: Khrystoforova Gully, south-facing slope with granite outcrops. May 2017, a month after the fire. Photo: Nina Polchaninova.

Slika 5: Jarek Khrystoforova, južno pobočje z granitnimi izdanki. Maj 2017, mesec po požaru. Foto: Nina Polchaninova.

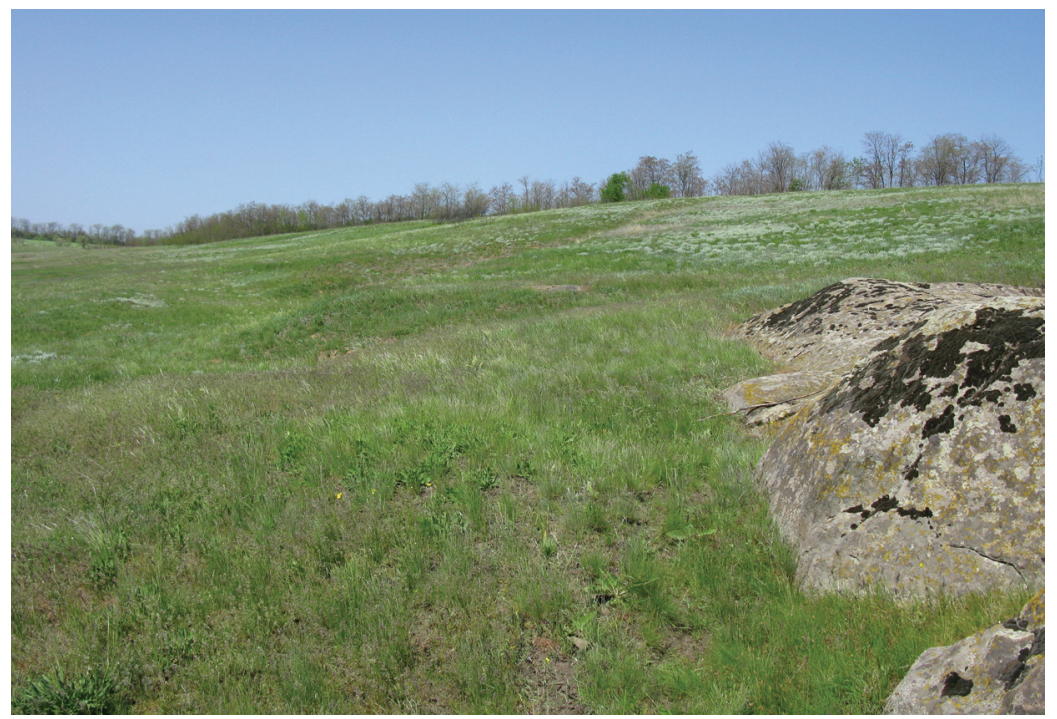

Figure 6: Zelena Gully, June 2017.

Photo: Nina Polchaninova.

Slika 6: Jarek Zelena, junij 2017.

Foto: Nina Polchaninova.

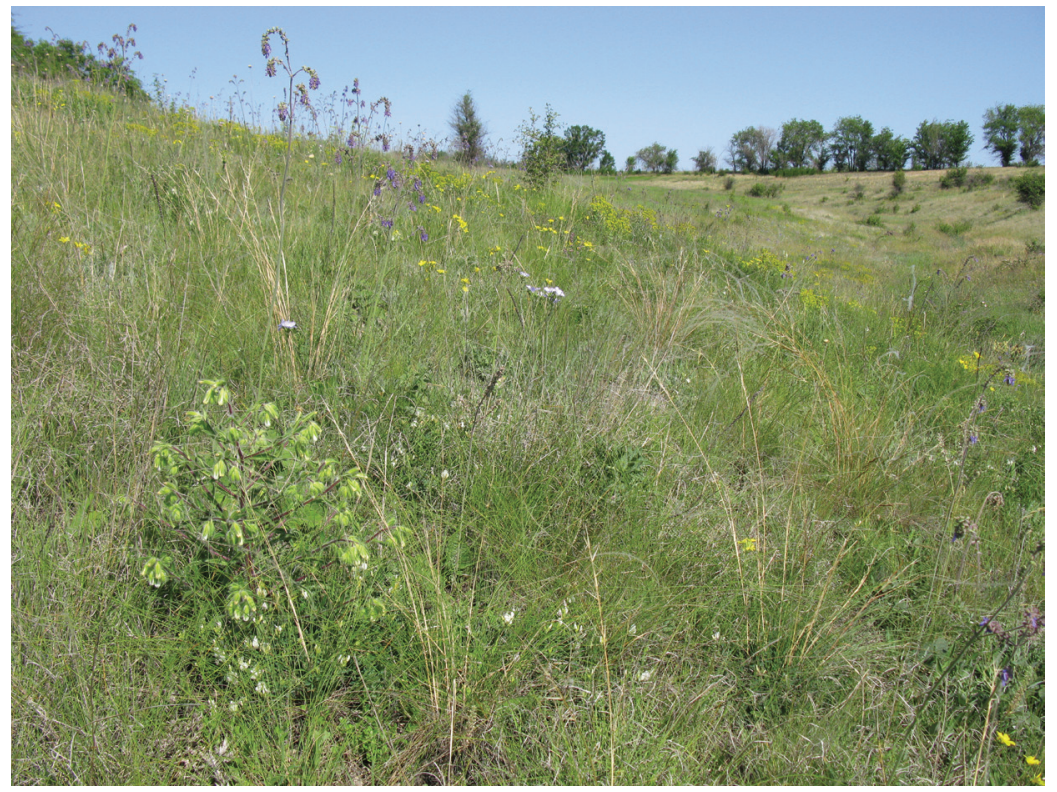

\section{Vegetation sampling and habitat classification}

In the course of the field studies in 2012-2017, a total of 122 geobotanical descriptions were made: Chervona Gully ( $\mathrm{n}=34$ ); Slate Rocks ( $\mathrm{n}=27$ ); Khrystoforova Gully $(n=22)$; Zelena Gully $(n=39)$. Sizes of sample plots depended on the type of habitat and ranged from $1 \times 1 \mathrm{~m}$ (rocky vegetation with mosses and lichens) to $5 \times 5 \mathrm{~m}$ (grassy communities and steppe scrub) (Pott 2011). Classification of the study habitats was adopted from the "National Habitat Catalogue of Ukraine" (Kuzemko et al. 2018). The habitats were identified to the level of vegetation associations (Figure 2, Table 1).

\section{Spider collection}

Spiders were collected in May-June 2017 by standard collecting methods: sweep netting, pitfall trapping and by hand. To cover habitat diversity of each site, we arranged sample plots at the gully bottoms and on the slopes of various expositions (Figure 2). At each sample plot, eight traps (300 $\mathrm{ml}$ plastic caps) were set up in a line, at a distance $10 \mathrm{~m}$ from each other. A $4 \%$ formalin solution served as preservative. The traps were exposed for 33 days.

A total of 11 plots were sampled at four sites (Figure 2), their vegetation characteristics and syntaxonomy is given in Table 1: Chervona Gully: ChG1 (1.1) - forb-fescue- 
Table 1: Xerothermic habitats of the study sites. Numbers and letters in bold indicate habitat location on the map (Figure 2) and abbreviations in the text. For the explanations, see Material and Methods.

Tabela 1: Kserotermni habitati na preučevanih mestih. Številke in črke, podarjene krepko, predstavljajo lokacijo habitata na karti (Slika 2) in okrajšave v besedilu. Za razlago glej poglavje Material in metode.

\begin{tabular}{|c|c|c|}
\hline $\begin{array}{l}\text { Syntaxa after } \\
\text { Prodrome of the vegetation of } \\
\text { Ukraine }\end{array}$ & $\begin{array}{c}\text { Habitats after } \\
\text { National Habitat Catalogue of } \\
\text { Ukraine }\end{array}$ & $\begin{array}{l}\text { Habitats after } \\
\text { EUNIS classification } \\
\text { adapted for Ukraine }\end{array}$ \\
\hline $\begin{array}{l}\text { Festuco-Brometea } \text { Br.-Bl. et Tx. ex Soo } 1947 \text {, } \\
\text { Tanaceto achilleifolii-Stipetalia lessingianae Lysenko et Mucina } \\
\text { in Mucina et al. 2016, } \\
\text { Poo bulbosae-Stipion graniticolae Vynokurov 2014, } \\
\text { Potentillo incanae-Seselietum pallasii Vynokurov } 2014 \\
\quad(3.2, \text { Kh2) }\end{array}$ & $\begin{array}{l}\text { T1. Dry grassy habitats } \\
\text { T1.2 Petrophytic steppes } \\
\text { T1.2.1 Petrophytic steppes on } \\
\text { siliceous substrata }\end{array}$ & $\begin{array}{l}\text { E1. Dry grasslands } \\
\text { E1.11 Euro-Siberian rock } \\
\text { debris swards }\end{array}$ \\
\hline $\begin{array}{l}\text { Potentillo arenariae-Linion czerniaevii Krasova et Smetana } \\
\text { 1999, } \\
\text { Lino tenuifolii-Jurineetum brachycephalae Krasova et Smetana } \\
1999 \text { (4.4, ZG4) }\end{array}$ & $\begin{array}{l}\text { T1.2.2.' } 6 \text { ' Petrophytic steppes on } \\
\text { carbonate substrata of the Black } \\
\text { Sea region }\end{array}$ & $\begin{array}{l}\text { E1.2 } \\
\text { (no equivalent) }\end{array}$ \\
\hline $\begin{array}{l}\text { Festucetalia valesiacae Soó } 1947, \\
\text { Festucion valesiacae Klika 1931, } \\
\text { Thalictro mini-Spiraeetum hypericifoliae Vynokurov } 2014 \\
\quad(\mathbf{1 . 3} \text {, ChG3), } \\
\text { Elytrigio trichophorae-Poetum angustifoliae Osychniuk et al. } \\
\quad \text { ex Solomakha } 1995 \text { (3.3, KhG3; 4.3, ZG3) }\end{array}$ & $\begin{array}{l}\text { T1.3 Meadow steppes } \\
\text { T1.3.2 Meadow steppes on } \\
\text { chernozems }\end{array}$ & $\begin{array}{l}\text { E1.23 Meso-xerophile } \\
\text { subcontinental } \\
\text { meadow-steppes }\end{array}$ \\
\hline $\begin{array}{l}\text { Tanaceto achilleifolii-Stipetalia lessingianae Lysenko et } \\
\text { Mucinain Mucina et al. 2016, } \\
\text { Stipo lessingianae-Salvion nutantis Vynokurov } 2014 \\
\text { Stipo lessingianae-Salvietum nutantis Vynokurov } 2014 \\
\text { (1.1, ChG1; 3.1, KhG1) } \\
\text { Tanaceto millefolii-Galatellion villosae Vynokurov in } \\
\text { Kolomiichuk et Vynokurov 2016 } \\
\text { Ephedro distachyae-Stipetum capillatae Kolomiychuk et } \\
\text { Vynokurov } 2016 \text { (4.1, ZG1) }\end{array}$ & $\begin{array}{l}\text { T1.4 True forb-fescue-feather } \\
\text { grass and fescue-feather grass } \\
\text { steppes } \\
\text { T1.4. a True forb- fescue-feather } \\
\text { grass and fescue-feather grass } \\
\text { steppes of the steppe zone }\end{array}$ & E1.2D Ponto-Sarmatic steppes \\
\hline $\begin{array}{l}\text { Rhamno-Prunetea Rivas Goday et Borja Carbonellex } \\
\text { Tüxen } 1961 \text {, } \\
\text { Prunetalia spinosae Tüxen } 1952, \\
\text { Prunion fruticosae Tx. 1952, } \\
\text { Amygdalo nanae-Spiraeetum hypericifoliae Fitsailo } 2008 \\
\quad \text { (1.2, ChG2; 4.2, ZG2) }\end{array}$ & $\begin{array}{l}\text { 'Ч’4. Deciduous shrubs } \\
\text { 'Ч'4.2 Steppe scrub }\end{array}$ & $\begin{array}{l}\text { F3.247 Ponto-sarmatic } \\
\text { deciduous thickets }\end{array}$ \\
\hline $\begin{array}{l}\text { Sedo-Scleranthetea Braun-Blanquet 1955, Trifolio arvensis- } \\
\text { Festucetalia ovinae Moravec 1967, Sempervivo-Sedion } \\
\quad \text { (Braun-Blanquet 1955) Müller } 1961 \\
\text { Sempervivo ruthenicae-Sedetum ruprechtii Didukh et Kontar } \\
\quad 1998(\mathbf{2}, \mathbf{S R})\end{array}$ & $\begin{array}{l}\text { K1. Siliceous rocks } \\
\text { K1.3 Siliceous rocks and screes of } \\
\text { the Ukrainian crystalline shield }\end{array}$ & $\begin{array}{l}\text { H3.19 Lowland northern- and } \\
\text { middle-European siliceous cliffs }\end{array}$ \\
\hline
\end{tabular}

feather grass steppe on a south-facing slope, ChG2 (1.2) steppe scrub on a north-facing slope, ChG3 (1.3) - meadow steppe at the gully bottom. Slate Rocks: SR (2) - steep stony slope with sparse vegetation. Khrystoforova Gully: KhG1 (3.1) - forb-fescue-feather grass steppe on a northfacing slope, KhG2 (3.2) - petrophyticsteppe on granite bedrock on the lower slope, Kh3 (3.3) - meadow steppe at the gully bottom. Zelena Gully: ZG1 (4.1) - forb-fescuefeather grass steppe on a south-facing slope, ZG2 (4.2) - steppe scrub on the upper slope, ZG3 (4.3) - meadow steppe at the gully bottom, ZG4 (4.4) - petrophytic steppe on limestone bedrock on a north-facing slope.

In addition, we set up four lines of traps in Chervona Gully from 9 to 29 September 2017. Since the study plot 
1.1 was burnt, we chose another plot with forb-fescuefeather grass vegetation and added steppe plots on silicate bedrock and old mound. The steppe scrub was sampled at the same plot (ChG2).

Herb-dwelling spiders were collected on 4-6 May, 8-10 June and 9 September by sweep netting. Spiders were swept near the trap lines and further along the slopes and/or gully bottoms. At least three samples of 50 sweeps were taken from each habitat.

\section{Data analysis}

We used criterion A (presence of threatened plant species) to evaluate botanical importance of the study sites (Anderson 2002, Onyshchenko 2017). We also followed criterion C (the presence of habitats from the Revised Annex I from the Resolution 4 of the Bern Convention 2019) to categorize the habitat conservation status and threat of its degradation under changing of grassland management, high recreation pressure, frequent burning and/or afforestation. We assessed floristic richness of the study habitats and compared them using Sørensen similarity index (Magurran 1991).

We defined spider species rarity based on their general geographic distribution (WSC 2020), distribution in the East European Plain (Mikhailov 2013, Polchaninova \& Prokopenko 2019; Nentwig et al. 2020), and habitat distribution within the steppe zone of Eastern Europe (Polchaninova \& Prokopenko 2013, 2017, Ponomarev 2017). The spider species list is arranged as a table indicating localities and habitats; autumnal collection is compiled in a separate column (Appendix, Table 2). We mentioned several species as juveniles, if adults from a certain locality were not recorded. The spider taxonomy follows WSC (2020); adult individuals were identified using Nentwig et al. 2020.

Given species habitat preferences, seven ecological groups of spiders were distinguished: $\mathrm{g}$-generalists, f/gr - inhabiting open forests, forest edges and mesic grasslands, f/dgr - same forest habitats and dry grasslands, gr - grasslands of various types, $\mathrm{mgr}$-wet and/or mesic grasslands, dgr - dry grasslands, st - steppe specialists, and a group of unspecified species (un) with data deficiency.

Comparison of the spider faunas of investigated habitats was based on the total list of species collected in May-June in the four study localities. Sørensen index was taken as a similarity measure (Magurran 1991). For convenience, we pooled the habitats SR, KhG2 and ZG4 into one group of "stony slopes". Hand collection and netting were used for faunistic assessment only, since they give a great number of juvenile spiders that cannot be identified to species. The results of autumnal pitfall trapping were included in the general species list.

The alpha (Shannon index) and beta (Whittaker index) diversity of spider assemblages (i.e. the measures that take into account the number of individuals of each species in a sample) were estimated based on May-June pitfall trap catches at each study plot separately. Only adult spiders, in total 576 individuals, were identified and counted. Detrended Correspondence Analysis (DCA) ordination of the study plots was also based on the species composition and activity density (ind./1 trap-day) of ground-dwelling spiders. Species recorded as singletons were excluded from the DCA procedure. All calculations were made in the program PAST, differences between the index values were estimated by means of permutation test. Statistical significance was set at $\mathrm{p}<0.05$. (Hammer et al. 2001).

\section{Results}

\section{Vegetation and habitats}

The vegetation communities described in our studies belong to eight associations, seven units, five orders and three classes (Dubyna et al. 2019). In terms of habitat diversity, they correspond to three higher taxa: $\mathrm{T}$ - grassy habitats, 'U' - shrubby habitats, and $\mathrm{K}$ - habitats of stony outcrops (Table 1).

Communities of the associations Stipo lessingianaeSalvietum nutantis and Ephedro distachyae-Stipetum capillatae occupy vast areas on the gentle slopes of all gullies, while the meadow steppe association Elytrigio trichophorae-Poetum angustifoliae was described only from the bottoms of Zelena and Khrystoforova gullies. An extrazonal meadow steppe association Thalictro mini-Spiraeetum hypericifoliae is formed near the foothills with silicate outcrops in mesic conditions. In our studies, this association was only found at the bottom of Chervona Gully. Steppe scrub (Amygdalo nanae-Spiraeetum hypericifoliae) is found as small patches in Chervona and Zelena gullies.

A total of 265 vascular plant species were recorded from 11 habitats in the four study sites. The richest was the flora of Zelena Gully - 179 species: an association Amygdalo nanae-Spiraeetum hypericifoliae (habitat ZG2, Table 1) was represented by 107 species, Lino tenuifolii-Jurineetum brachycephalae (ZB4) by 99 species, Ephedro distachyaeStipetum capillatae (ZG1) by 91 species, and Elytrigio trichophorae-Poetum angustifoliae (ZG3) by 84 species. The floristic richness of Chervona Gully was slightly lower, 172 species, but there, only three habitats were investigated: Stipo lessingianae-Salvietum nutantis (ChG1) - 116 species, Amygdalo nanae-Spiraeetum hypericifoliae (ChG2) - 99 species, and Thalictro mini-Spiraeetum hypericifoliae 
(ChG3) - 63 species. The flora of Khrystoforova Gully, comprising 119 recorded species, was the poorest. It numbered 84 species in Stipo lessingianae-Salvietum nutantis association (KhG1), 48 species in Elytrigio trichophoraePoetum angustifoliae (KhG3), and only 15 species in Potentillo incanae-Seselietum pallasii (KhG2). The association Sempervivo ruthenicae-Sedetum ruprechtii on the Slate Rocks (SR) comprised 50 recorded species.

Cluster analysis based on the sintaxon floristic composition showed the highest similarity of the associations Stipo lessingianae-Salvietum nutantis in Chervona and Khrystoforova gullies (Sørensen ind. 75\%) (Figure 7, habitats ChG1, KhG2). They form one cluster with the associations of forb-fescue feather grass, petrophytic, meadow steppes and the steppe scrub of Zelena Gully. Other associations do not create a separate group but consequently join the first one. The most different was the association Potentillo incanae-Seselietum pallasii on the granite substrate in Khrystoforova Gully with the very low similarity level of $12 \%$.

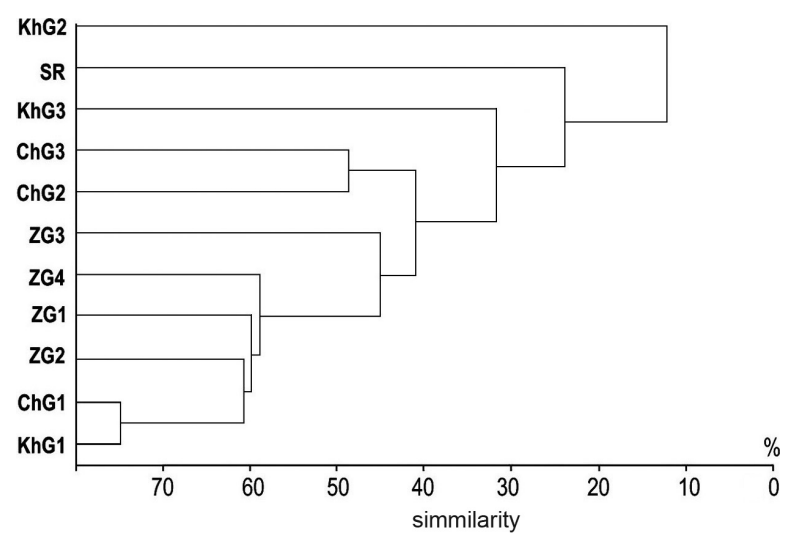

Figure 7: Dendrogram of floristic similarity of the vegetation of the study habitats (Sørensen index). For abbreviations, see Table 1.

Slika 7: Dendrogram floristične podobnosti vegetacije preučevanih habitatov (Sørensenov indeks). Za okrajšave glej Tabela 1.

The investigated sites host 23 vascular plant species that have been added to the Red Lists of various ranks or categorized as being under threat (Appendix, Table 1). In the Red Data Book of Ukraine (Didukh 2009), nine plant species recorded from the study area were assigned to the category vulnerable, two species - nearly threaten nine species - least concern, and two species of data deficiency. Zelena Gully was the richest in the number of protected species (18), ten species were recorded from Chervona Gully, eight species from Khrystoforova Gully and only three species from the Slate Rocks. In terms of habitat preferences, the distribution of rare species was as follows: T1.2.1 - 0, T1.2.2.'б' - 9, T1.3 - 4, T1.4.a - 15, 'Ч'4.2 - 5, and K1.3 - 2 species (Appendix, Table1).

\section{Spiders}

A total of 95 spider species from 20 families were recorded from the dry grassland habitats of the study area (Appendix, Table 2). Of these, 55 species were found from the stony slopes, 58 species from the forb-fescue-feather grass steppe, 51 species from the steppe scrub, and 47 species from the meadow steppes at the gully bottoms. Spider species richness was highest in the forb-fescue-feather grass steppe and steppe scrub (30-34 species in each locality), as well as in the meadow steppe in Zelena Gully (31 species). The most variable was the number of species on the stony slopes (from 12 to 24, Appendix, Table 2). The spring-summer spider fauna of Zelena Gully was the most species-rich, while that of Khrystoforova Gully was the poorest (62 and 48 species, respectively). In Chervona Gully, 55 species were found in May-June and only an additional nine species in autumn.

The spider faunistic similarity was highest at the two plots of forb-fescue-feather grass steppe (ChG1/ $\left.\mathrm{ZG1}, \mathrm{K}_{\mathrm{s}}=0.60\right)$ and lowest at the plots of stony slopes $\left(\mathrm{K}_{\mathrm{s}}=0.27-0.33\right)$ (Figure 8). A comparison of the spider species composition of various habitats within one site showed highest $\mathrm{K}_{\mathrm{s}}$ values in Zelena Gully (ZG1/ZG2 0.56 , ZG1/ZG4 - 0.56, and ZG2/ZG3 - 0.58). At other sites, it ranged from 0.27 (KhG2/KhG3) to 0.52 (ChG1/ ChG2), being lowest in Khrystoforova Gully (Figure 8).

The stony slopes were the richest in the number of rare spider species (12 out of 19) while the meadow steppes were the poorest (3 species). Seven rare species were found in the forb-fescue-feather grass steppes and four species in the steppe scrub. Zelena Gully hosted ten rare species, Chervona Gully eight species, and Khrystoforova Gally only three species. Species distribution by ecological groups was as follows: 7 generalists, 19 forest-grassland species, 9 forest-dry grassland species, 9 grassland species, 29 dry grassland species, 19 steppe specialists and 5 species with unclear preferences. The number of steppe specialists decreased from 11 in Chervona and Zelena gullies to four in the Khrystoforova one (Appendix, Table 2).

The ground-dwelling spider assemblage of the Slate Rocks was the most diverse, showing significant differences with the five studied assemblages out of ten (Figure 9). Among the five, there were spiders of the two forb-fescuefeather grass steppe habitats and the two meadow ones, as well as spiders of petrophytic steppe in the Khrystoforova Gully. The Shannon indices of other spider assemblages did not differ so pronouncedly, still they were higher at both plots of steppe scrub and in the petrophytic steppe in Zelena Gully.

Beta-diversity (Whittaker index) of the ground-dwelling spiders of the study localities decreased as follows: 
Forb-fescue-feather grass steppes

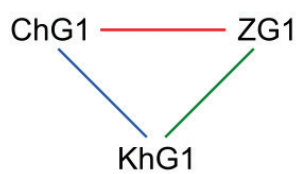

Meadow steppes

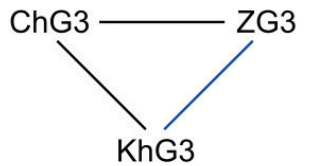

Steppe scrub

ChG2

ZG2

Stony slopes

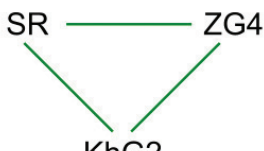

KhG2
Chervona Gully

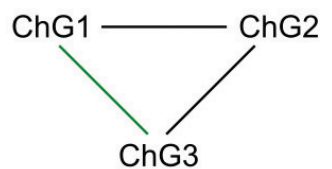

Khrystoforova Gully

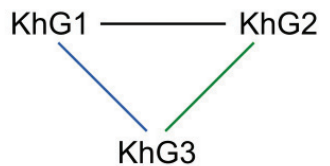

Zelena Gully

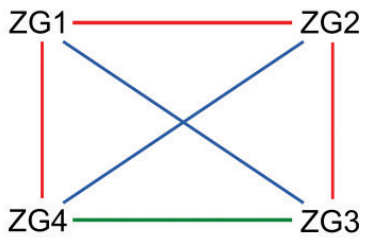

Figure 8: Similarity of the spider species composition of various habitats (Sørensen index values: $0.27-0.33$ - green line, $0.36-0.42$ - blue line, $0.49-0.52$ - black line, $0.56-0.60$ - red line. For abbreviations, see Table 1.

Slika 8: Podobnost vrstne sestave pajkov v različnih habitatih (vrednosti Sørensenovega indeksa: 0,27-0,33 - zelena črta, 0,36-0,42 - modra črta, 0,49-0,52 - črna črta, 0,56-0,60 - rdeča črta. Za okrajšave glej Tabela 1.

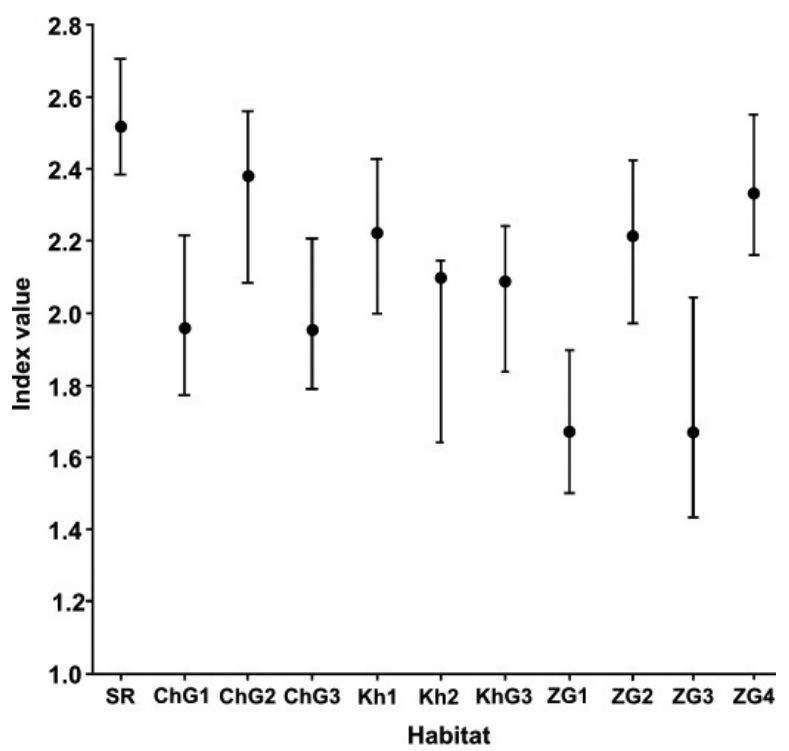

Figure 9: Species diversity of the ground-dwelling spider assemblages of the study plots (Shannon index). Whiskers indicate min and max bootstrap values. For abbreviations, see Table 1 .

Slika 9: Vrstna pestrost združb pajkov, ki prebivajo na tleh na preučevanih ploskvah (Shannonov indeks). Ročaji predstavljajo minimalne in maksimalne vrednosti, dobljenih z zankanjem. Za okrajšave glej Tabelo 1 .

Zelena Gully (1.327), Chervona Gully (1.002), and Khrystoforova Gully (0.846). In terms of habitat preferences, spiders of meadow steppes showed low beta diversity $\left(\mathrm{K}_{\mathrm{w}}=0.588\right)$ while in the other habitats, it was equally high (stony slopes -1.100 , steppe scrub -1.071 , forb-fescue-feather grass steppes - 1.069).

DCA ordination of the study habitats based on species and individual abundances of the ground-dwelling spiders showed a grouping of the forb-fescue-feather grass and petrophytic steppes of Chervona and Zelena gullies, a middle position of the steppe scrub and meadow steppes of the same gullies, and location of the three Khrystoforova Gully plots on the highest extremities of Axis 1 (Figure 10). The Slate Rocks and the granites in Khrystoforova Gully differed along Axis 2, being at the maximal distance from the meadows of Chervona and Zelena gullies.

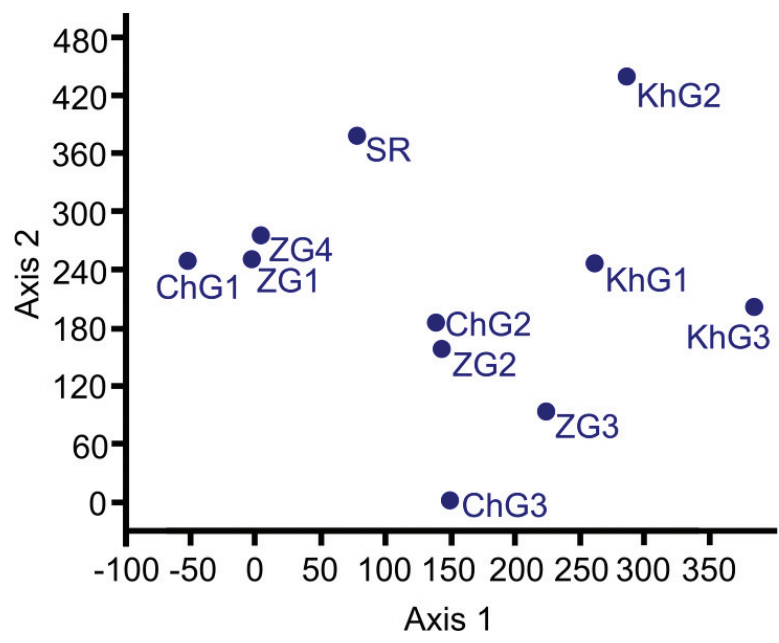

Figure 10: Detrended Correspondence Analysis ordination of the study habitats based on the ground-dwelling spider species composition and individual numbers. For abbreviations, see Table 1.

Slika 10: DCA ordinacija preučevanih habitatov na osnovi vrstne sestave talnih pajkov in števila osebkov. Za okrajšave glej Tabelo 1 .

\section{Discussion}

Xerothermic habitats of the middle reaches of the Inhulets River basin belong to the three main types: dry grassy habitats, deciduous shrubs and siliceous rocks. All of them are under protection of the Resolution 4 of the Bern Convention (Revised Annex I 2019). The habitats T1.2, T1.3, and T1.4 correspond to the category E1.2 Perennial calcareous grasslands and basic steppes, the habitats ' $\mathrm{Y}$ ' to F3.247 Ponto-Sarmatic deciduous thickets, and the habitats ' $\mathrm{K}$ ' to H3.1 Acid siliceous inland cliffs. In the frame of the Habitats Directive (Council Directive 1992), the investigated meadow, petrophytic and true steppes belong 
to the priority habitats $62 \mathrm{C} 0^{*}$ Ponto-Sarmatic steppes, the shrub steppes to $40 \mathrm{~A} 0 *$ Subcontinental peri-Pannonic scrub, and the siliceous outcrops to 8230 Siliceous rock with pioneer vegetation of the Sedo-Scleranthion or of the Sedo albi-Veronicion dillenii.

Comparison of floristic composition of the vegetation of the study habitats showed the highest similarity (75 $\%)$ of the associations Stipo lessingianae-Salvietum nutantis in Khrystoforova and Chervona gullies located at the north of the study area. In Zelena Gully, the vegetation of the same associations differed significantly due to the site specificity. In the case of steppe scrub with a dominance of Caragana frutex (L.) K. Koch (ass. Amygdalo nanaeSpiraeetum hypericifoliae), the difference is determined by edaphic conditions: carbonate bedrocks in Zelena Gully and siliceous bedrocks in Chervona Gully. The association Elytrigio trichophorae-Poetum angustifoliae, formed at the bottom of Zelena Gully, was rich in calcareous grassland species, while that of the Khrystoforova Gully included a number of ruderal species appeared due to human economic activity.
The extremely poor flora of Potentillo incanae-Seselietum pallasii association (15 species) can be explained by the specificity of its habitat. This vegetation is formed on shallow eluvial sediments on the surface in the cracks of granite boulders. Compared with the vegetation of granite bedrocks, the communities of Slate Rocks are richer due to more favourable edaphic conditions (50 species).

The spider fauna of the study sites is characteristic of xerothermic habitats. Dry grassland and steppe species comprise together $50 \%$ of the fauna; open forest-dry grassland inhabitants add a further $9 \%$. The two studied gullies, Chervona and Zelena, are well preserved and have a high conservation value. The local communities can serve as a pattern of spider species composition and habitat preferences in the south of the forb-fescue-feather grass steppe subzone (Polchaninova 2012). Khrystoforova Gully is highly disturbed by continuous grazing and uncontrolled fires. The spider community responds to these impacts with a decrease in the total species richness and the number of rare species and steppe specialists. In this

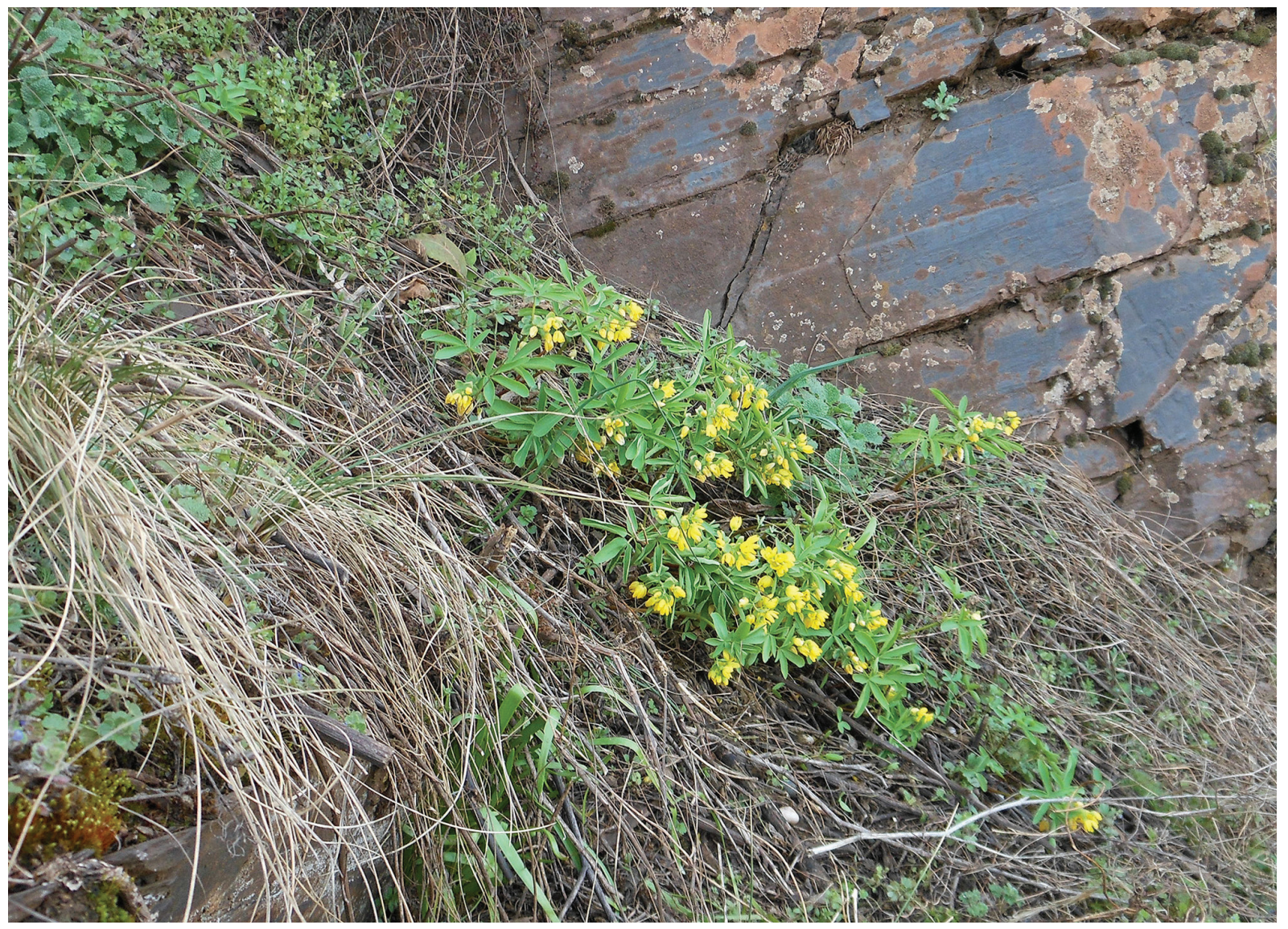

Figure 11: Gymnospermium odessanum and Allium lineare on the Slate Rocks. Photo: Olga Krasova.

Slika 11: Gymnospermium odessanum in Allium lineare na skrilastem skalovju. Foto: Olga Krasova. 
gully, spider assemblages of the same habitat type differ from those in Zelena and Chervona gullies (Figure 8).

At the same time, frequent fires that destroy a thick litter layer seem to enable a high number and abundance in flowering early-spring plant species (Adonis wolgensis, A. vernalis, Bulbocodium versicolor). Previously we observed a similar pattern in Zelena Gully: a comparison of geobotanical descriptions taken before and after the fire confirmed an increase of the early-blossoming plant abundance at the fire site. Khrystoforova Gully hosts eight protected plant species.

Spider research revealed 19 rare species (Appendix, Table 2). For Harpactea azovensis and Zelotes eugeni, this is the most northwestern known locality; these species' ranges stretch from the Dnipropetrovska Oblast and Crimea of Ukraine to Rostov-on-Don Oblast of Russia (Kovblyk \& Kastrygina 2015). For Dysdera hungarica, this is the northernmost locality on the East European Plain. Gnaphosa opaca has been recorded in Ukraine from the Dnipropetrovska and Mykolaivska (NP unpublished) oblasts only. Micaria bosmansi has not been found west of the Dnipropetrovska Oblast. Euryopis saukea is a North American invasive species, now patchily distributed in the Palearctic nemoral belt. The other 13 species in this list are regionally rare. Mainly they are common inhabitants of the dry grasslands and/or open forests in Southern Ukraine and in the South East of European Russia and spread north via azonal habitats (Polchaninova \& Prokopenko 2013, Ponomarev 2017).

In the basin of the Inhulets middle reaches, the largest number of rare plant and spider species are associated with the forb-fescue-feather grass and petrophytic calcareous steppes. Zonal forb-fescue-feather grass steppes cover vast areas at all study sites and host 15 rare plant species and seven spider species. In the petrophytic steppes, which are patchy and smaller, the proportion is inverse, with more spider species (11) and less plant species (9).

Stony slopes of various bedrocks have long been known as hotspots of regionally rare and specialist species (Sobko 1972, Buchar \& Růžička 2002) even if they are of anthropogenic origin and/or experience high

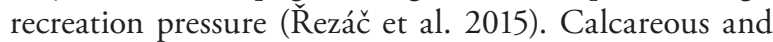
crystalline outcrops in the East European Plain create mountain-like conditions, which favor the formation of a biota markedly different from that of the surrounding zonal landscapes and contribute to the spread of southern species to the north (Kontar 2001, Polchaninova \& Prokonenko 2013). In our study, the Slate Rocks and the limestone slopes in Zelena Gully hosted the highest proportion of rare spiders (17\% and 29\% respectively). Moreover, despite the small area and high recreation pressure, the Slate Rocks preserve populations of a plethora of protected plants. They are a refuge for a narrow-range endemic species of the crystalline outcrops of the south of the Dnieper Upland, Sedum borissovae Balk. (Sobko 1972), and the northernmost detached locality of Gymnospermium odessanum (Figure 11). The narrow broken strips of the forb-fescue-feather grass steppe on the rocks' flattened upper part are a habitat of Tulipa hypanica and Stipa ucrainica. Among the species of the genus Stipa of the plain Ukraine, S. ucrainica is one of the most sensitive to anthropogenic impacts. In the area in hand, its assemblages were recorded in small fragments only.

Interestingly, the spider species richness in various habitats followed floristic richness, being higher in the forb-fescue-feather grass steppe and steppe scrub and lower in the meadow steppe. Both were the poorest on the granite and slate outcrops, while the petrophytic steppe on limestone soil was rich in plant but poor in spider species.

The valley of the Inhulets middle reaches, along with the gullies flowing into it, was added to the "Shadow list" (NGO lobby for new conservation areas) and then to the list of the Emerald Network sites of Ukraine (No. UA0000310, Updated list 2019). Unfortunately, only Zelena Gully has got the "Emerald status", since its flora has a high number of protected plant species (18). There are endemic species of calcareous steppes that determine uniqueness of this site. To our mind, steppe gullies and crystalline rocks of the Saksahan River basin, the Inhulets largest tributary, are also sites of conservation concern. Given coenotic and habitat diversity of the Slate Rocks and Chervona Gully, located in its valley, this area requires protection in accordance with European standards. If it receives Emerald status, it may be excluded from the plans of mining expansion, which is currently the greatest threat to natural habitats in the study area. Moreover, this status would give legal grounds to control recreation and grazing intensity and recommend prescribed burning to help avoid uncontrolled fires.

\section{Conclusion}

Botanical and arachnological evaluations of priority areas complement each other and make the assessment more profound. Rich vegetation and spider communities with rare and specialist species in Zelena Gully confirm its high conservation status. The Slate Rocks and Chervona Gully are recommended to be included into the Emerald Network, since they host well-preserved natural habitats listed in the Resolution 4 of the Bern Convention as well as a number of protected and rare species. 


\section{Acknowledgements}

The authors are thankful to Dr. Stephen Venn as the Coordinating Editor and the two anonymous Reviewers for the valuable comments on the initial draft. The linguistic proofreading made by Dr. Stephen Venn is also deeply acknowledged.

Nina Polchaninova (D) https://orcid.org/0000-0003-4605-8788

Olga Krasova (D) https://orcid.org/0000-0003-3035-5614

Liudmyla Lysohor (D) https://orcid.org/0000-0002-1949-1394

TatianaAtemasova D https://orcid.org/0000-0002-7527-5143

\section{References}

Anderson, S. 2002: Identifying important plant areas: a site selection manual for Europe. Plantlife International, 52 pp.

Batáry, P., Holzschuh, A., Orci, K. M., Samu, F. \& Tscharntke, T. 2012: Responses of plant, insect and spider biodiversity to local and landscape scale management intensity in cereal crops and grasslands. Agriculture, Ecosystems and Environment 146 (1): 130-136. DOI: https://doi.org/10.1016/j.agee.2011.10.018

Birkhofer K., Diekötter, T., Meub, C., Stötzel, K. \& Wolters, V. 2015: Optimizing arthropod predator conservation in permanent grasslands by considering diversity components beyond species richness. Agriculture, Ecosystems and Environment 211: 65-72.

DOI: https://doi.org/10.1016/j.agee.2015.05.014

Braschler, B \& Baur, B. 2016: Diverse effects of a seven-year experimental grassland fragmentation on major invertebrate groups. PLoS ONE 11(2): e0149567. DOI: https://doi.org/10.1371/journal. pone. 0149567

Buchar, J. \& Rủžička, V. 2002: Catalogue of spiders of the Czech Republic. Peres, Praha, 351 pp.

Buchholz, S. 2010: Ground spider assemblages as indicators for habitat structure in inland sand ecosystems. Biodiversity and Conservation 19(9): 2565-2595. DOI: https://doi.org/10.1007/s10531-010-9860-7

Cardoso, P., Silva, I., De Oliveira, N.G. \& Serrano, A.R.M. 2004: Indicator taxa of spider (Araneae) diversity and their efficiency in conservation. Biological Conservation 120(4): 517-524.

DOI: https://doi.org/10.1016/j.biocon.2004.03.024

Convention on the Conservation of European Wildlife and Natural Habitats 1979: Bern, 19.IX.1979 (ETS No 104).

Council Directive 92/43/EEC of 21 May 1992 on the conservation of natural habitats and of wild fauna and flora, O.J. L206, 22.07.92

Deli, O. F. 2014: Spider complexes of the ecosystems at the different transformation stages in the northwestern Black Sea Region. Abstract of thesis for the scientific degree of Candidate in Biological Sciences. I. I. Mechnikov Odessa National University, Odesa, 21 pp. [In Ukrainian with English summary].

Didukh, Y. P. (Ed.). 2009: Red Data Book of Ukraine. Plant Kingdom. Hlobalkonsaltynh, Kyiv, 912 pp. [In Ukrainian].

Didukh, Y. P. \& Shelyag-Sosonko, Y. R. 2003: Geobotanical regioning of Ukraine and adjacent territories. Ukrainskyi Botanichnyi Zhurnal 60(1): 6-17 [in Ukrainian with English summary].
Dubyna, D. V., Dziuba, T. P., Yemelianova, S. M. et al. 2019: Prodrome of the vegetation of Ukraine. Naukovadumka, Kyiv. 783 pp. [In Ukrainian].

Gajdoš, P., Moscaliuc, L.A. \& Rozwalka, R. (eds) 2014: Red list of spiders (Araneae) of the Carpathian Mts., pp. 82-135. In: Kadlečik, J. (ed.), Draft Carpathian red list of forest habitats and of species draft Carpathian list of invasive alien species, Štat na ochrana prirody Slovenskej republiky, Banska Bystrica, 234 pp.

Hammer, Ø., Harper, D. A.T. \& Ryan, P. D. 2001: PAST: paleontological statistics software package for education and data analysis. Palaeontologia Electronica 4 (1): 1-9.

Harlio, A., Kuussaari, M., Risto, K., Heikkinen, R. K. \& Arponen, A. 2019: Incorporating landscape heterogeneity into multi-objective spatial planning improves biodiversity conservation of semi-natural grasslands. Journal for Nature Conservation 49: 37-44.

DOI: https://doi.org/10.1016/j.jnc.2019.01.003

Iosypchuk, A. M. 2019: First data on the spider fauna (Araneae) of the National Nature Park 'Kamyanska Sich' (South Ukraine), In A.V. Akulov et al. (eds). From a Molecula to the Biosphere. Abstract of XIV International Young Scientists' Conference (November 27th - 29th, 2019), Kharkiv, pp. 169-171.

IUCN Red List of Threatened Species. Version 2020-1. International Union for Conservation of Nature and Natural Resources. Mode of access https://www.iucnredlist.org/ (Accessed on 15 October 2020).

Knappová, L., Hemrova, L. \& Münzbergová, Z. 2012: Colonization of central European abandoned fields by dry grassland species depends on the species richness of the source habitats: a new approach for measuring habitat isolation. Landscape Ecology 27: 97-108. DOI: https://doi.org/10.1007/s10980-011-9680-5

Kontar, I. S. 2001: Differentiation of the Polissya and Forest Steppe of Ukraine crystal rock outcrops vegetation cover. Abstract of thesis for the scientific degree of Candidate in Biological Sciences. M.G. Kholodny Institute of Botany of the National Academy of Sciences of Ukraine, Kyiv, 20 pp. [in Ukrainian with English summary].

Kovblyuk, M. M. \& Kastrygina, Z. A. 2015: Updated catalogue of the spiders (Arachnida, Aranei) of the Crimea. Ukrainska Entomofaunistyka 6(2): 1-81 [in Russian].

Krasova O. O., Polchaninova N. Yu. \& Lysogor L. P. 2020: Xerothermic habitats of the Kryvyi Rih part of the River Inhulets basin: conservation value in botanical and arachnological aspects. In: Monitoring and biodiversity conservation in Ukraine: Plants and fungi / Series: 'Conservation Biology in Ukraine' 16(1), Druk Art, Kyiv, Chernivtsi, pp. 116-125. [in Ukrainian].

Kuzemko, A. A., Didukh, Ia. P., Onyshchenko, V. A. \& Sheffer, Ya. (eds) 2018: National habitat catalogue of Ukraine. FOP Klymenko Iu.Ia., Kyiv, 442 pp. [In Ukrainian].

Lafage, D., Maugenest, S., Bouzillé, J.-B. \& Pétillon, J. 2015: Disentangling the influence of local and landscape factors on alpha and beta diversities: opposite response of plants and ground plants ground-dwelling arthropods in wet meadows. Ecological Research 30: 1025-1035. DOI: https://doi.org/10.1007/s11284-015-1304-0

Magurran, A. 1991: Ecological diversity and its measurements. Chapman and Hall, London, 178 pp.

Mikhailov, K. G. 2013: The spiders (Arachnida: Aranei) of Russia and adjacent countries: a non-annotated checklist. Arthropoda Selecta, Supplement 3: 1-262. 
Nentwig, W., Blick, T., Gloor, D., Hänggi, A. \& Kropf, C. 2020: Araneae. Version 12.2020. https://www.araneae.nmbe.ch (accessed 6.12.2020)

Niemelä, R. \& Baur, B. 1998: Threatened species in a vanishing habitat: plants and invertebrates in calcareous grasslands in the Swiss Jura Mountains. Biological Conservation 7: 1407-1416.

DOI: https://doi.org/10.1023/A:1008835529764

Öberg, S., Mayr, S. \& Dauber, J. 2008: Landscape effects on recolonisation patterns of spiders in arable fields. Agriculture, Ecosystems and Environment 123: 211-218. DOI: https://doi org/10.1016/j.agee.2007.06.005

Onyshchenko, V. A. (ed.) 2017: Important Plant Areas of Ukraine. Alterpress, Kyiv, 376 pp.

Outhwaite, C. L., Gregory, R. D., Chandler, R. E., Collen, B. \& Isaac, N. J. B. 2020: Complex long-term biodiversity change among invertebrates, bryophytes and lichens. Nature Ecology and Evolution 4: 384-392. DOI: https://doi.org/10.1038/s41559-020-1111-z

Perner, J. \& Malt, S. 2003: Assessment of changing agricultural land use: Response of vegetation, ground-dwelling spiders and beetles to the conversion of arable land into grassland. Agriculture, Ecosystems and Environment 98: 169-181. DOI: https://doi.org/10.1016/S01678809(03)00079-3

Poggio, S. L., Chaneton, E. J. \& Ghersa, C. M. 2010: Landscape complexity differentially affects alpha, beta, and gamma diversities of plants occurring in fencerows and crop fields. Biological Conservation 143: 2477-2486. DOI: https://doi.org/10.1016/j.biocon.2010.06.014

Polchaninova, N. 2012: Assemblages of herb-dwelling spiders (Araneae) of various steppe types in Ukraine and the Central Chernozem region of Russia. Arachnologishe Mitteilungen Bd. 43 (2): 66-78.

Polchaninova, N. Yu., Gnelitsa, V. A., Evtushenko, K. V. \& Singaevsky, E. N. 2017: An annotated checklist of spiders (Arachnida: Aranei) of the National Nature Park 'Buzkyi Hard' (Mykolaiv Area, Ukraine). Arthropoda Selecta 26(3): 253-272.

Polchaninova, N. Yu. \&Prokopenko, E. V. 2013: Catalogue of the spiders (Arachnida, Aranei) of Left-Bank Ukraine. Arthropoda Selecta, Supplement 2: pp. 1-268.

Polchaninova, N. Yu. \&Prokopenko, E. V. 2017: Catalogue of the spiders (Arachnida, Aranei) of Left-Bank Ukraine. Addendum I. 2013-2016. Mikhailov K.G. (ed.). Arthropoda Selecta, Supplement 4: pp. 1-115.

Polchaninova, N. \& Prokopenko, E. 2019: An updated checklist of spiders (Arachnida: Araneae) of Left-Bank Ukraine. Arachnologische Mitteilungen 57(1): 60-64.

Polchaninova, N., Savchenko, G., Ronkin, V., Drogvalenko, A. \& Putchkov, A. 2019: Summer fire in steppe habitats: a long-term effect on vegetation and autumnal assemblages of cursorial arthropods. Hacquetia 18: 213-231. DOI: https://doi.org/10.2478/hacq-20190006

Ponomarev, A. V. 2017: Spiders (Arachnida: Aranei) of steppe and meadow-steppe habitats of gully and ravine ecosystems of the valley of the Don River lower reaches. Proceedings of the Russian Entomological Society 88 (1): 118-131 [in Russian with English summary].

Pott, R. 2011: Phytosociology: A modern geobotanical method. Plant Biosystems 145: 9-18. DOI: https://doi.org/10.1080/11263504.201 1.602740
Prokopenko, E. V. \& Zhukov, O. V. 2018: Spider (Aranei) steppe community in a ravine with fescue-feather-grass petrophytic vegetation. Acta Biologica Sibirica 4: 17-21. [in Russian with English summary]

Revised Annex I of Resolution 4 (1996) of the Bern Convention on endangered natural habitats types using the EUNIS habitat classification (Adopted by the Standing Committee on 6 December 2019). Mode of access https://rm.coe.int/16807469e7

Řezáč, M., Kůrka, A., Růžička, V. \& Heneberg, P. 2015: Red list of Czech spiders: 3rd edition, adjusted according to evidence-based national conservation priorities. Biologia 70: 645-666.

DOI: https://doi.org/10.1515/biolog-2015-0079

Rodriguez-Artigas, S. M., Ballester, R. \& Corronca, J. A. 2016: Factors that influence the beta-diversity of spider communities in northwestern Argentine an Grasslands. PeerJ, pp. 1-19. DOI: https:// doi.org/10.7717/peerj.1946

Smetana, O. M. \& Smetana, N. M. 2005: Structure of terrestrial mesofauna in Kryvbas. Phitosotsiotsentr, Kyiv, 227 pp. [in Russian].

Sobko, V. G. 1972: Endemic and relic elements of the flora of the granite outcrops of the Dnieper Upland. Ukrainian Botanical Journal 29 (5): 624-630. [in Ukrainian]

Szmatona-Túri, T., Vona-Túri, D., Urbán, L., Weiperth, A. \& Magos, G. 2019: How grassland management methods affect spider diversity. Acta-Universitatis-Sapientiae, Agriculture and Environment 11: 23-37.

Tamme, R., Hiiesalu, I., Laanisto, L., Szava-Kovats, R. \& Pärtel, M. 2010: Environmental heterogeneity, species diversity and co-existence at different spatial scales. Journal of Vegetation Science 21(4): 796-801. DOI: https://doi.org/10.1111/j.1654-1103.2010.01185.x

Tokarsky, V. A. (ed.) 2013: Red Data Book of Kharkiv Region of Ukraine. Animals. V. N. Karazin Kharkiv National University, Kharkiv, 472 pp. [in Ukrainian]

Updated list of officially adopted Emerald sites (December 2019). Mode of access https://rm.coe.int/updated-list-of-officially-adoptedemerald-sites-december-2019-/168098ef51?fbclid=IwAR3Sfh-F_w0fp HBkCggkU1Xc1bUbo57vMgDhu1Fcgq-gFvM5QaceWsnOlt4

WSC 2020: World Spider Catalog. Natural History Museum Bern, online at http://wsc.nmbe.ch, version 21.5

Zalevskiy, V. D. \& Bronskov, A. I. (eds.) 2017: Red Data Book of Donetsk Region: Animals. Scientific information guide. PJSC "Vinnytsia Regional Printing House»", Vinnytsia, 452 pp. [in Ukrainian].

Zao, Z., Reddi, G. V. P., Wei, S., Zhu, M., Zhang, K., Yu, H., Wang Z., Jiang, Q. \& Zhang, R. 2018: Plant cover associated with aboveground net primary productivity (ANPP) mediates insect community composition in steppes of Northwest China. Journal of Asia-Pacific Entomology 21: 361-366.

Zografou, K., Adamidis, G. C., Komnenov, M., Kati, V., Sotirakopoulos, P., Pitta, E. \& Chatzaki, M. 2017: Diversity of spiders and orthopterans respond to intra-seasonal and spatial environmental changes. Journal of Insect Conservation 21(3): 531-543.

DOI: https://doi.org/10.1007/s10841-017-9993-z 


\section{Appendix}

Table 1: Rare vascular plant species at the study sites / habitats in the basin of the Inhulets middle reaches

Tabela 1: Redke rastlinske vrste na preučevanih rastiščih/habitatih v srednjem teku reke Inhulets.

\begin{tabular}{|c|c|c|c|c|c|c|}
\hline Species & $\stackrel{\bigodot}{<}$ & 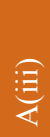 & $\stackrel{\Xi}{\&}$ & $\begin{array}{l}\Xi \\
Z \\
己\end{array}$ & $\stackrel{\varrho}{\varrho}$ & Sites and habitats \\
\hline Adonis vernalis $\mathrm{L}$. & . & . & . & . & NT & ChG (1.1-1.3); KhG (3.1); ZG (4.1-4.4) \\
\hline Adonis wolgensis Stevenex DC. & . & . & . & . & NT & ChG (1.1-1.3); KhG (3.1); ZG (4.1-4.3) \\
\hline Allium lineare L. & . & . & . & . & $\mathrm{LC}$ & SR (K1.3) \\
\hline Astragalus henningii (Steven) Klokov & . & . & . & . & VU & ZG (T1.4.a) \\
\hline Astragalus dasyanthus Pall. & . & . & . & . & DD & $\operatorname{ChG}(1.1,1.2) ; \operatorname{KhG}(3.1)$ \\
\hline Astragalus odessanus Besser & . & . & . & . & VU & ZG (T1.4.a) \\
\hline Bulbocodium versicolor (Ker-Gawl.) Spreng. & . & . & . & . & LC & KhG (3.1); ZG (4.1) \\
\hline Caragana scythica Pojark. & . & . & + & . & VU & ZG (4.1) \\
\hline Cytisus graniticus Rehmann & . & + & . & . & VU & ZG (4.3) \\
\hline Crocus reticulatus Steven ex Adams & . & . & . & . & $\mathrm{LC}$ & KhG (3.1); ZG (4.1) \\
\hline Elymus stipifolius (Trautv.) Melderis & + & & & LC & $\mathrm{LC}$ & ZG (4.3) \\
\hline Eremogone cephalotes (Bieb.) Fenzl & . & + & . & . & VU & ZG (4.1) \\
\hline Genista scythica Pacz. & . & + & . & . & $\mathrm{LC}$ & ZG (4.3) \\
\hline Gymnospermium odessanum (DC.) Takht. & . & . & + & . & VU & SR (K1.3) \\
\hline Iris pontica Zapal. & . & . & + & . & VU & ZG (T1.4.a) \\
\hline Ornithogalum boucheanum (Kunth) Asch. & . & . & . & . & $\mathrm{LC}$ & ChG (T1.3.2) \\
\hline Pulsatilla pratensis (L.) Mill. & . & . & . & . & LC & ChG (1.3); KhG (3.1); ZG (4.3) \\
\hline Stipa asperella Klokov et Ossycznjuk & . & . & . & . & DD & ZG (4.3) \\
\hline Stipa capillata $\mathrm{L}$. & . & . & . & . & LC & $\operatorname{ChG}(1.1,1.2) ; \operatorname{KhG}(3.1) ; Z$ ZG (4.1-4.3) \\
\hline Stipa lessingiana Trin. etRupr. & + & . & . & LC & LC & $\operatorname{ChG}(1.1,1.2) ; \operatorname{KhG}(3.1) ; Z G(4.1-4.3)$ \\
\hline Stipa pulcherrima K. Koch & . & . & . & . & VU & ChG (T1.4.a) \\
\hline Stipa ucrainica P. Smirn. & . & . & . & . & LC & ChG (T1.4.a), SR (T1.4a); ZG (T1.4.a) \\
\hline Tulipa hypanica Klokov et Zoz & . & + & . & . & VU & ChG (T1.4.a); SR (T1.4a); ZG (T1.2.2.‘б’) \\
\hline Total species & 2 & 4 & 3 & 2 & 23 & \\
\hline
\end{tabular}

Abbreviations: A(i) - species with categories CR and VU in the IUCN database, version 2020-2; A(iii) - species with categories "endangered" and "vulnerable" in the Red Data Book of Ukraine (Didukh 2009) that are considered national endemics of Ukraine; A(iv) - limited range species with categories "endangered" and "vulnerable" in the Red Data Book of Ukraine that are not national endemics; IUCN RL - species included in the IUCN Red List of threatened species (IUCN version 2020); RDBU - species listed in the Red Data Book of Ukraine. Categories: DD - data deficient, i.e. insufficient information for a proper assessment of conservation status to be made; LC - least concern, unlikely to become extinct in the near future; NT - near threatened, close to being at high risk of extinction in the near future; VU -vulnerable, likely to become endangered unless the circumstances that are threatening their survival and reproduction improve.

Sites and habitats. SR - Kryvyi Rih Town, Slate Rocks; ChG - Kryvyi Rih Town, Chervona Gully: ChG1 - forb-fescuefeather grass steppe, ChG2 - steppe scrubs, ChG3 - meadow steppe, ChGa - autumnal collection in various habitats; KhG - Kudasheve Vil., Khrystoforova Gully: KhG1 - forb- fescue-feather grass steppe, KhG2 - petrophytic steppe on granite bedrock, KhG3 - meadow steppe; ZG - Poltavka Vil., Zelena Gully: ZG1 - forb- fescue-feather grass steppe, ZG2 - steppe scrubs, ZG3 - meadow steppe, ZG4 - petrophytic steppe on limestone bedrock. (Figures 1, 2). If a species was not found at the sample plots marked on the map, we indicated the type of habitat at the study site where it was recorded. 


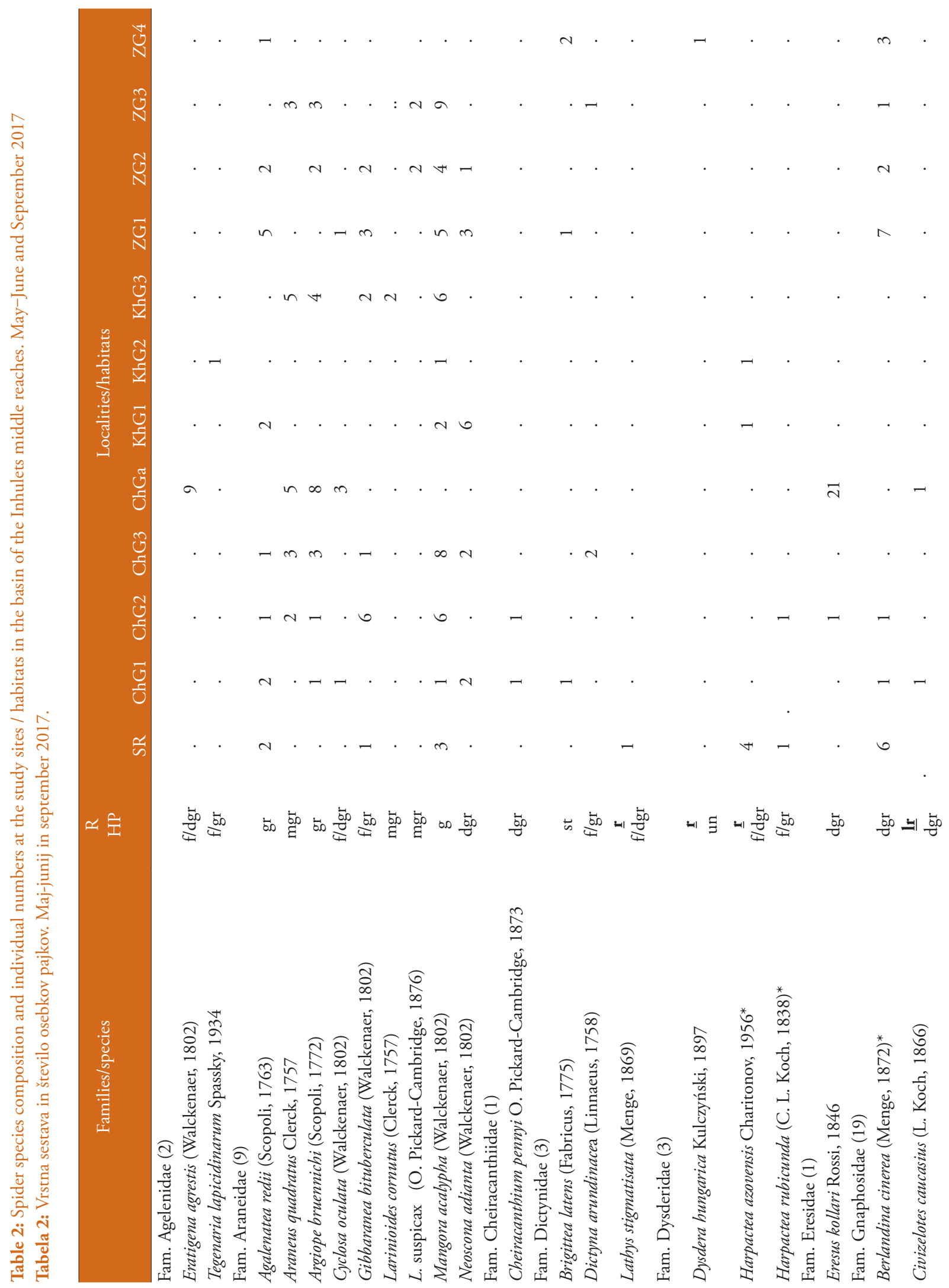




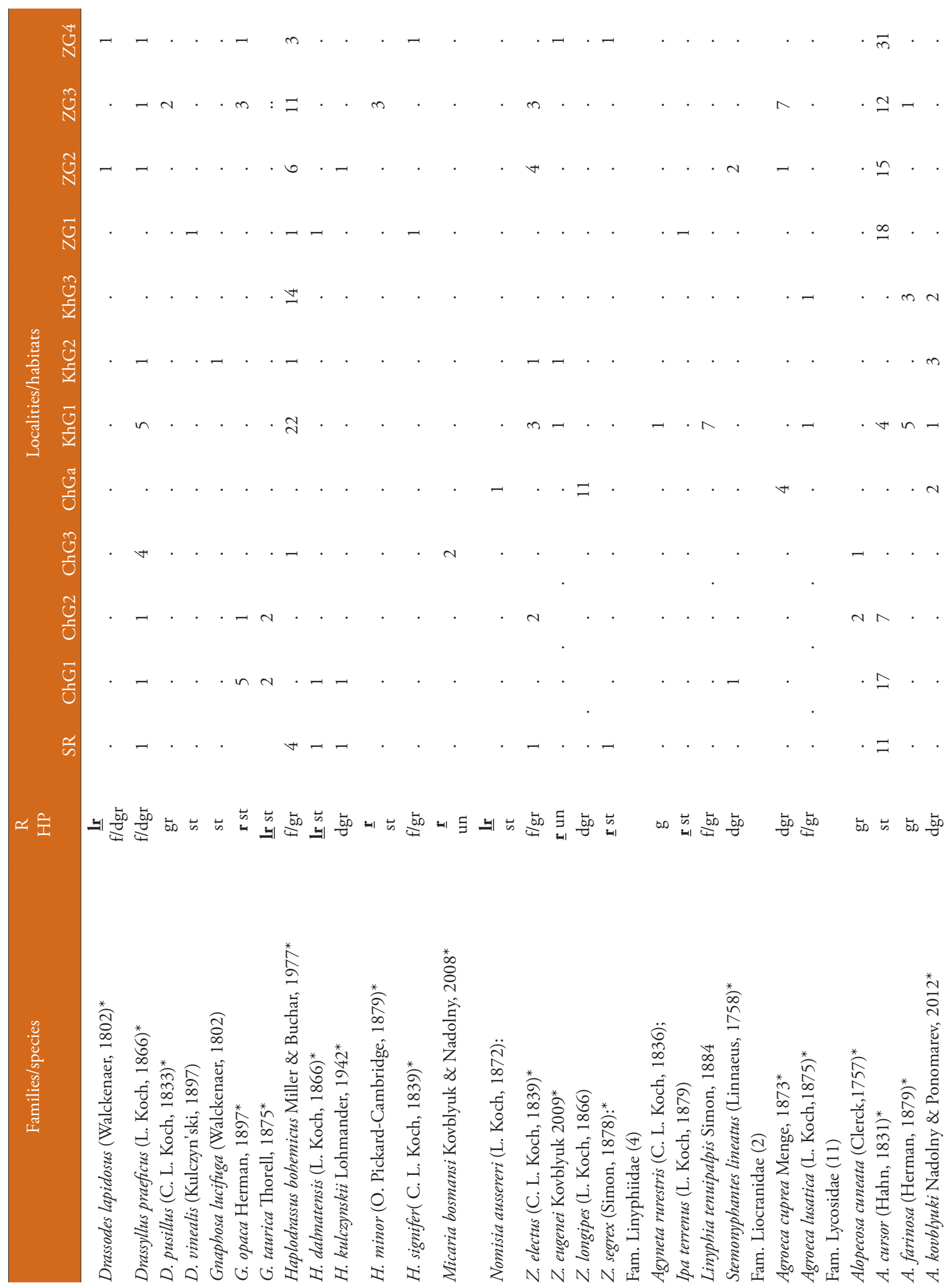




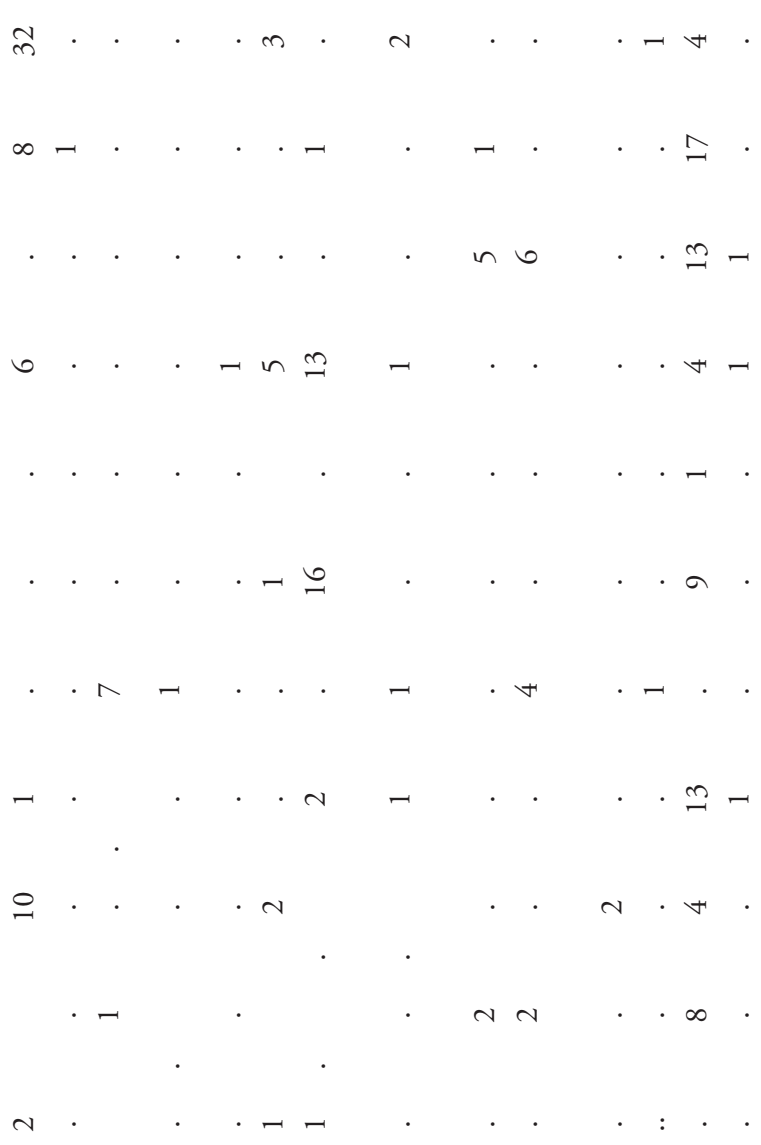

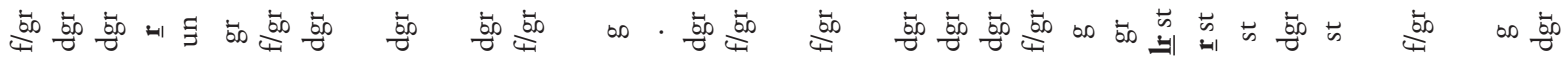

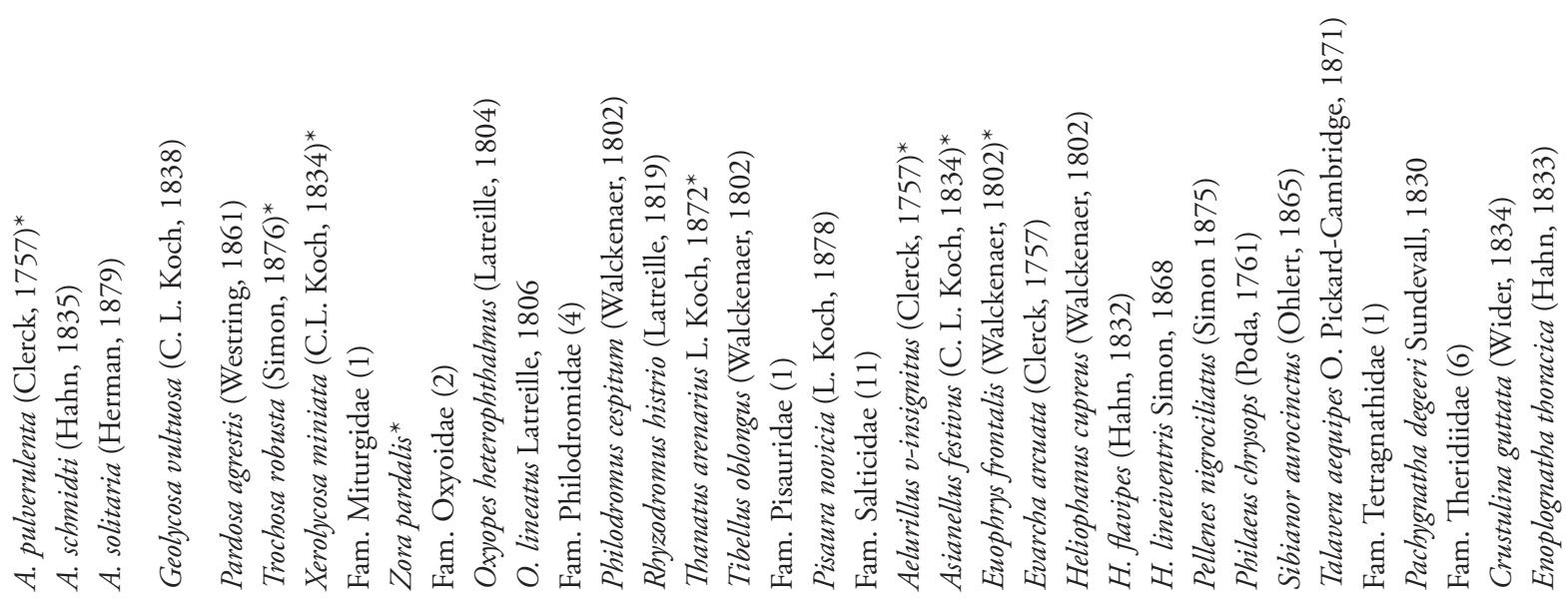




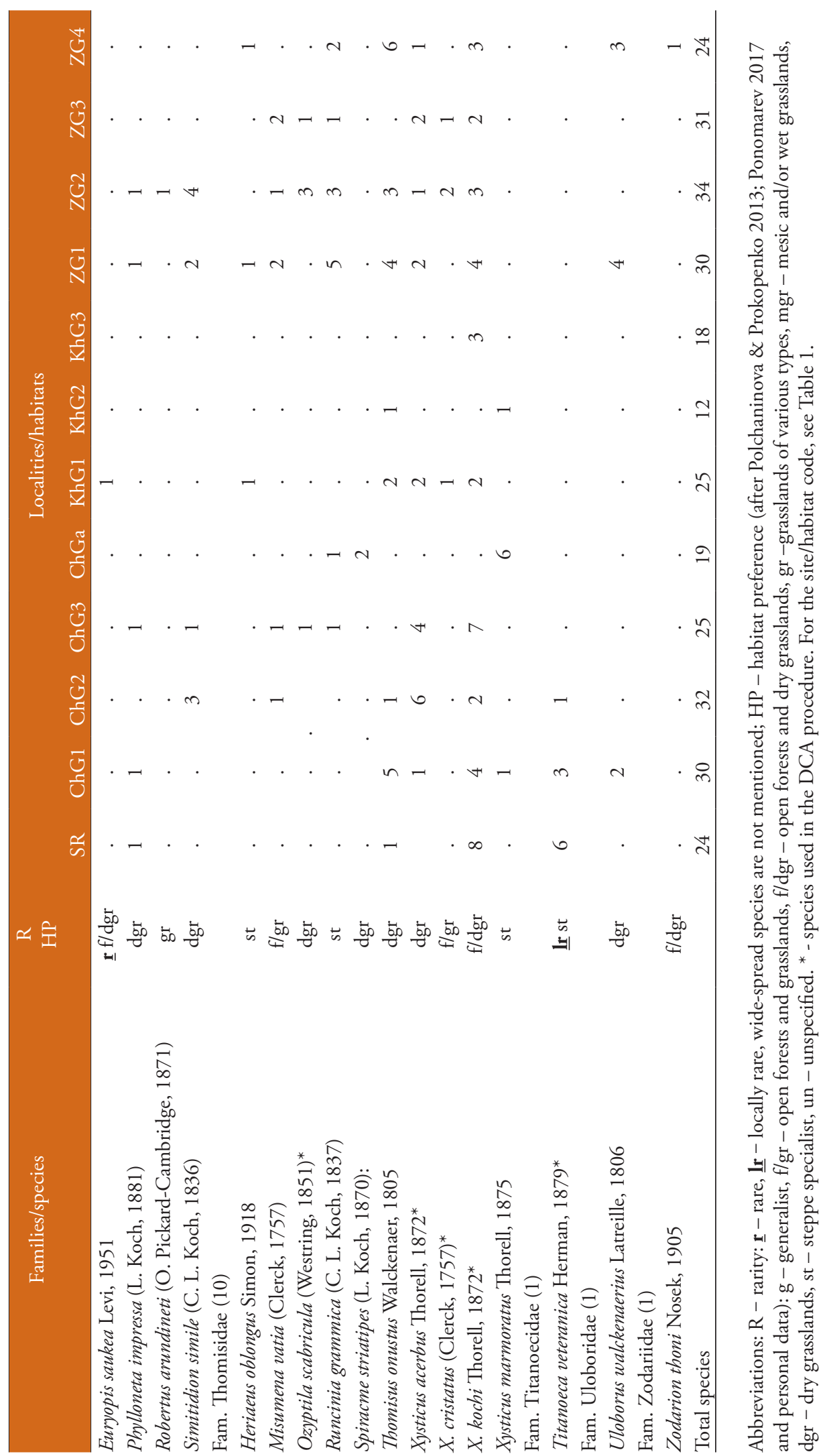

